\title{
MELATIH KARAKTER KEWIRAUSAHAAN SISWA SMK MELALUI PEMASARAN ONLINE
}

\author{
Tri Winarsih 1, Yono Dwi Widodo 2 \\ 1 butriwin@gmail.com , ${ }^{2}$ yonodwiwidodo@gmail.com \\ 1,2 Magister Pendidikan Ekonomi Universitas Nusantara PGRI Kediri
}

\begin{abstract}
Abstrak
Guna menumbuhkan jiwa wirausaha di kalangan siswa SMK bukanlah hal yang mudah apalagi mereka masih berusia belia di mana aktivitasnya masih banyak dipengaruhi dengan dunia bermain dengan teman-teman sepergaulannya. Namun bukan berarti ini tidak mungkin dilakukan. Di sinilah peran guru khususnya pengampu mata pelajaran Produk Kreatif dan Kewirausahaan (PKK) sangat dituntut kreatifitasnya sehingga siswa mau mencoba menjadi wirausaha. Salah satu upaya yang dapat dilakukan untuk menumbuhkan jiwa wirausaha adalah dengan melatih karakter siswa menjadi wirausaha.Tujuan penelitian ini untuk mendeskripsikan cara melatih karakter wirausaha siswa SMK melalui pemasaran online. Metode penelitian ini adalah deskriptif. Hasil penelitian menunjukkan adanya keberhasilan dari beberapa siswa memulai usahanya dengan melakukan pemasaran online. Hasil yang diperoleh dari 33 siswa yang melaksanakan praktek kewirausahaan, ternyata mayoritas memasarkan produknya berupa kuliner yaitu 28 orang, sementara empat orang memasarkan produk kosmetik dan satu orang memasarkan produk aksesoris. Dari seluru hsiswa yang telah memasarkan produknya tersebut memang tidak semuanya mendapatkan laba. Hal ini dapat dilihat ada 9 siswa yang tidak mendapatkan laba, sedang 24 siswa yang lain mendapatkan laba yang bervariasi. Ada beberapa faktor yang menyebabkan beberapa siswa tidak mendapatkan laba yaitu karena kurang telaten, salah dalam memperhitungkan harga jual dan konsumen kurang berminat dengan produk yang dipasarkan
\end{abstract}

Kata Kunci: Karakter kewirausahaan, pemasaran online, motivasi berprestasi

\section{PENDAHULUAN}

Indonesia merupakan salah satu negara yang memiliki potensi besar untuk memajukan perekonomiannya baik dari sumberdaya alam maupun sumberdaya manusiannya. Dilihat dari sisi SDM nya Indonesia termasuk negara yang beruntung karena memiliki penduduk dengan usia produktif yang lebih banyak atau dikenal dengan bonus demografi. Peluang inilah yang seharusnya bisa dimanfaatkan pemerintah untuk memajukan perekonomian bangsa (Anas, Riani and Lianawati, 2019). Seperti kita ketahui bahwa Indonesia saat ini masih sedikit yang menggeluti dunia wirausaha yaitu sekitar 1,5\% dari jumlah penduduk negeri ini. Padahal jumlah ideal yang diharapkan adalah 2 sampai $3 \%$ persen dari populasi penduduk dapat menjadi wirausaha sehingga akan membantu mencapai kemakmuran ekonomi.

Lembaga sekolah khususnya SMK merupakan sarana strategis untuk menumbuhkan jiwa wirausaha. Hal ini karena sekolah adalah institusi pendidikan yang dipercaya masyarakat untuk membawa masa depan lebih baik. SMK juga merupakan sekolah formal di bawah Departemen Pendidikan Nasional yang bertujuan menghasilkan tamatan siap memasuki dunia kerja secara mandiri sebagai wirausaha (entrepreneur). Dan saat ini pemerintah telah merancang kurikulum SMK 
dengan memasukkan mata pelajaran Produk Kreatif dan Kewirausahaan yang jumlah jamnya cukup banyak yaitu kelas XI 7 jam dan kelas XII 8 jam. Dengan jumlah jam yang demikian banyak tersebut diharapkan siswa terbekali dengan ilmu dan keterampilan yang akan menjadi menjadi bekal hidup di masyarakat (Anas, 2019).

Untuk menumbuhkan jiwa wirausaha dalam diri siswa bukanlah hal yang mudah apalagi harus mempraktekkannya dalam kehidupan sehari-hari dengan membuka sebuah usaha. Tapi bukan berarti ini tidak mungkin dilakukan. Di sini dibutuhkan beberapa upaya melatih karakter siswa sebgai persiapan berwirausaha (Ahmad, 2021). Dengan beberapa kompetensi dasar yang akan disajikan di pembelajaran Produk Kreatif dan Kewirausahaan diharapkan guru bisa mengarahkan siswa untuk mencoba berwirausaha.

Kewirausahaan atau biasa disebut entrepreneurship dalam Bahasa Inggris, sebenarnya berasaldari Bahasa Perancis yaitu entreprende yang berarti petualang, pencipta dan pengelola usaha. Istilah ini diperkenalkan pertama kali oleh (Cherukara and Manalel, 2011). Dalam perkembangannya istilah ini semakin popular setelah digunakan oleh pakar ekonomi (McFarlane, 2016). Menuru tkeputusan Menteri Koperasi dan Pembinaan Pengusaha Kecil Nomor 961/KEP/M/N/1995 adalah semangat, sikap, perilaku dan kemampuan seseorang untuk menangani usaha atau kegiatan yang mengarah pada upaya mencari, menciptakan, menerapkan cara kerja, teknologi dan produk baru dengan meningkatkan efisiensi dalam rangka memberikan pelayanan yang lebih baik atau memperoleh keuntungan yang lebih besar.

Menurut (Brown and Thornton, 2011), kewirausahaan lebih merujuk kepada sifat, watak dan ciri-ciri yang melekat pada seseorang yang mempunyai kemauan keras untuk mewujudkan gagasan inovatif kedalam dunia usaha yang nyata dan dapat mengembangkannya dengan tangguh. Oleh karena itu, dengan mengacu kepada orang yang melaksanakan proses gagasan dan memadukan sumberdaya menjadi realitas, muncul apa yang dinamakan wirausaha (entrepreneur). (Megawati and Farida, 2018) menyatakan bahwa kewirausahaan dan wirausaha merupakan faktor produksi aktif yang dapat menggerakkan dan memanfaatkan sumberdaya lainnya, seperti sumberdaya alam, modal dan teknologi sehingga dapat mencipakan kekayaan dan kemakmuran melalui penciptaan lapangan kerja, penghasilan serta produk yang diperlukan masyarakat. Sementara menurut (Grebel, 2004), kewirausahaan sering dikaitkan dengan proses, pembentukan atau pertumbuhan suatu bisnis baru yang berorientasi pada perolehan keuntungan, penciptaan nilai serta pembentukan produk atau jasa baru yang unik dan inovatif. Jadi secara umum dapat disimpulkan yang dimaksud dengan kewirausahaan adalah kemampuan dan tindakan untuk menciptakan sesuatu yang dapat memberikan peluang dan nila itambah.

Istilah wirausaha mengacu pada orang atau subyek yang melaksanakan tindakan kewirausahaan. Wirausaha adalah orang yang menciptakan peluang dan nila itambah melalui gagasan baru, memadukan sumberdaya dan merealisasikan gagasan tersebut menjadi kenyataan (Handayani et al., 2021). Ide serta gagasan tersebut dibuat dalam bentuk bisnis yang berjalan dan mendapatkan hasil. Menurut (Gawel, 2021), wirausaha adalah orang yang bertanggungjawab dalam menyusun, mengelola dan mengukur risiko suatu usaha. (Atiya and Osman, 2021) menyatakan bahwa wirausaha atau entrepreneur merupakan pengusaha yang melakasanakan kombinasikombinasi baru dalam bidang teknik dan komersial kedalam bentuk praktek. Sedangkan menurut (Fierro and Andrade, 2021), wirausaha merupakan orang yang mengorganisasi, mengelola dan berani menanggung risiko untuk menciptakan usaha baru dan peluang usaha.

Salah satu jenis usaha yang sedang marak saat ini adalah berjualan secara online atau biasa dikenal dengan bisnis online. Dengan memanfaatkan media sosial seperti Whatsapp, Facebook marketplace, Instagram, Youtube dan sebagainya dapat menjadi sarana bagi mereka yang mau memulai usaha onlinenya (Artantri et al., 2021). Memang media Bsosial ini semakin popular sebagai alat marketing, sebab konsumen dimudahkan membeli produk tanpa harus mendatangi toko dan bertatap muka dengan penjualnya. Cukup dengan memilih produk atau jasa yang diinginkan dan barang dapat dikirim dalam waktu yang telah disepakati penjual dan pembeli. 
Berdasarkan latar belakang di atas maka dapat dirumuskan masalah, bagaimana melatih jiwa wirausaha pada siswa SMK melalui bisnis online? Tujuan dari penelitian ini untuk memaparkan cara melatih jiwa wirausaha bagi siswa SMK melalui bisnis online.

\section{METODE PENELITIAN}

Penelitian ini menggunakan penelitian deskriptif, yaitu penelitian yang dilakukan untuk mengetahui dan menjadi mampu untuk menjelaskan tentang melatih karakter wirausa hasiswa SMK melalui pemasaran online. Subyek penelitian ini adalah siswa SMK Negeri 2 Blitar, kelas XII OTKP 3, Tahun Pembelajaran 2020/2021. Penelitian dilakukan dengan cara mengambil data siswa praktek pemasaran online, matapelajaran Produk Kreatif dan Kewirausahaan. Selain itu juga dengan melakukan wawancara terhadap siswa yang telah melakukan pemasaran online.

\section{PEMBAHASAN}

Wirausaha dapat menumbuhkan seseorang untuk mamapu berpikir penuh perhitungan serta mencari pilihan dari berbagai alternatif masalah dan pemecahannya (Zhuravlov et al., 2021). Untuk menjadi wirausahawan seseorang harus memiliki karakter, meliputi: memeiliki kepercayaan diri yang kuat, berorientasi tugas dan hasil, berani mengambil resiko, memiliki jiwa kepemimpinan, mampu menciptakan sesuatu yang orisinil (inovatif), dan visioner atau berorientasi ke masa depan. Guna menjadi seorang wirausaha harus dimiliki orientasi kedepan, memiliki visi yang jelas, berfikir positif dan memiliki pengetahuan yang luas. Karakter berikutnya yang harus dimiliki wirausaha adalah siap menghadapi perubahan dengan cara berpikir keras, menyenangkan, proaktif, kreatif, inovatif, efisien, produktif dan orisinal. Selain itu seorang wirausaha juga harus memiliki jaringan usaha, jaringan kerja, banyak teman dan kerjasama yang baik dengan semua pihak. Seorang wirausaha yang tangguh memiliki jiwa kepemimpinan dengan keberanian bertindak, tim yang baik, berjiwa besar, berani mengambi Iresiko, memiliki mentor, terbuka, kepercayaan. Terakhir, seorang wirausaha harus memiliki karakter motivasi berprestasi, pekerja keras, tidak menyerah, semangat dan memiliki komitmen (Jayanti et al., 2021).

Ada pepatah mengatakan bahwa hasil tidak akan menghianati usaha. Ini berarti bahwa ketika akan mencapai sesuatu haruslah berproses sebab tidak ada yang instan untuk sebuah hasil yang maksimal. Demikian pula untuk menjadi wirausaha yang sukses tentunya harus dimulai sejak dini. Saat siswa masih duduk di bangku sekolah sudah harus dilatih dan dikembangkan karakternya menjadi wirausaha sehingga kelak sudah siap melangkah yang lebih jauh lagi dalam dunia usaha. Berbagai cara dapat digunakan untuk melatih ssiswa dan menumbuhkan karakter wirausaha dalam ranka mempersiapkan siswa untuk menjadi wirausahawan. Pada tabel 1. Disajikan cara melatih karakter siswa untuk persiapan berwirausaha.

Tabel 1 Cara melatih karakter siswa guna persiapan berwirausaha

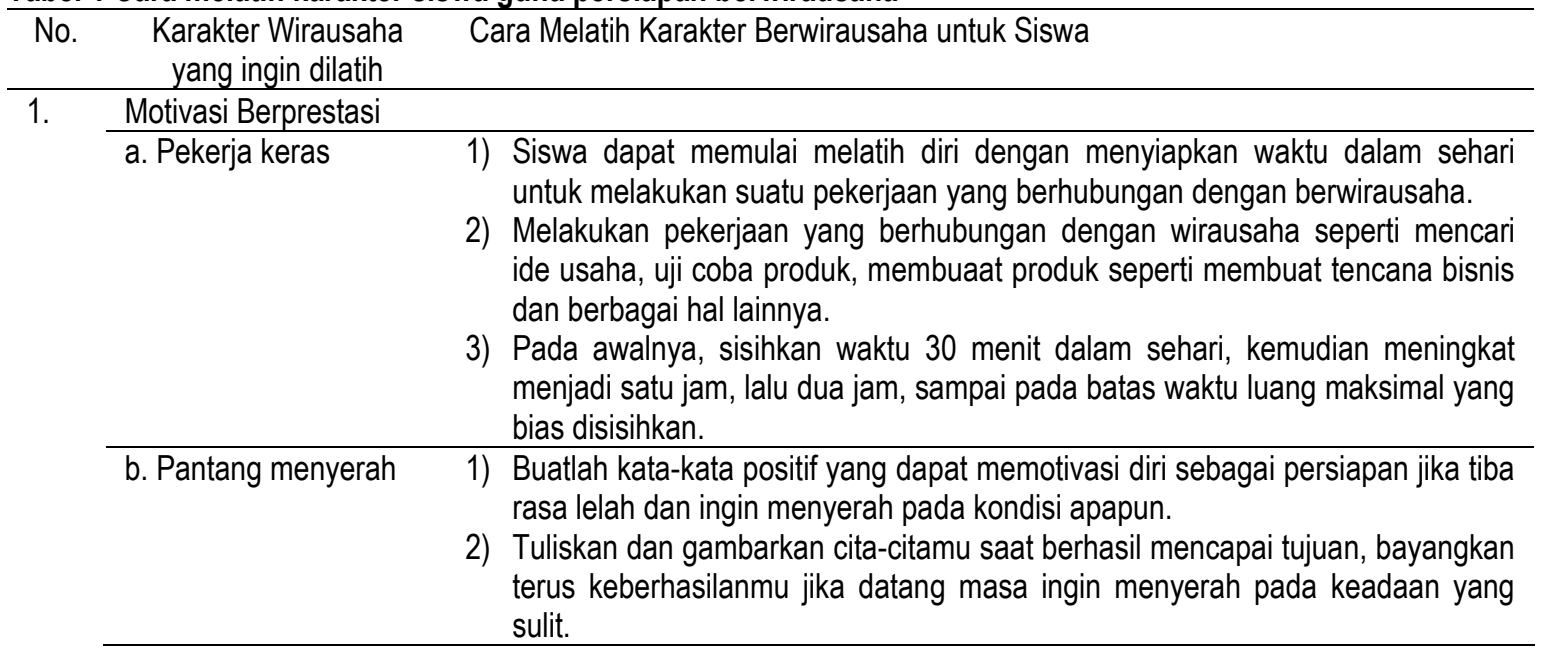




\begin{tabular}{|c|c|c|}
\hline \multirow[t]{7}{*}{ No. } & $\begin{array}{l}\text { Karakter Wirausaha } \\
\text { yang ingin dilatih }\end{array}$ & Cara Melatih Karakter Berwirausaha untuk Siswa \\
\hline & \multirow{3}{*}{ c. Semangat } & 1) Rajin berolah raga agar kondisi fit. \\
\hline & & 2) Ketika kondisi fit, siswa akan lebih bersemangat. \\
\hline & & $\begin{array}{l}\text { 3) Pilih bidang usaha yang disukai dan diminati agar saat mengerjakan nya selalu } \\
\text { bersemangat. }\end{array}$ \\
\hline & \multirow[t]{3}{*}{ d. Komitmen } & $\begin{array}{l}\text { 1) Latihan sederhana untuk berkomitmen dapat dilakukan dengan mengerjakan } \\
\text { satu hal yang sulit kamu lakukan, seperti mengulangi pelajaran sekolah selama } \\
\text { tiga puluh menit sehari, diet sehat, tidak terlambat, atau sholat } 5 \text { waktu bagi } \\
\text { yang beragama Islam. }\end{array}$ \\
\hline & & 2) Coba untuk melatihnya terus selama tiga bulan dan usahakan untuk komitmen. \\
\hline & & $\begin{array}{l}\text { 3) Setelah tiga bulan terus dilakukan, komitmen mu ini akan menjadi sebuah } \\
\text { kebiasaan baru yang akan membuatmu menjad ilebih baik. }\end{array}$ \\
\hline \multirow[t]{9}{*}{2.} & \multicolumn{2}{|l|}{ Orientasi ke depan } \\
\hline & \multirow[t]{3}{*}{ a. Visioner } & $\begin{array}{l}\text { 1) Cobalah untuk melatih intuisimu dan melakukan pengamatan untuk melihat hal } \\
\text { yang dibutuhkan generasimu tahun depan dan tahun sesudahnya pada bidang } \\
\text { usahamu. }\end{array}$ \\
\hline & & $\begin{array}{l}\text { 2) Catat sesuai dengan imajinasi dan pengamatanmu, tuliskan pula tanggalnya } \\
\text { dan simpan selama satu tahun. Setelah satu tahun, bukalah dan lihat apa yang } \\
\text { terjadi? Apakah tepat ada beberapa yang tepat atau bahkan tidak ada sama } \\
\text { sekali? }\end{array}$ \\
\hline & & 3) Latih terus setiap tahun untuk mengasah intuisi visionermu. \\
\hline & \multirow[t]{2}{*}{ b. Berpikirpositif } & $\begin{array}{l}\text { 1) Cara mudah untuk melatih pikiran positif adalah ketika dating pikiran atau } \\
\text { emosi negative, berikan jeda pada dirimu sendiri untuk menenangkan diri dan } \\
\text { mengalihkan pikiran pada hal positif yang menyenangkan. }\end{array}$ \\
\hline & & $\begin{array}{l}\text { 2) Jika hal ini dilakukan secara terus menerus, kamu akan memiliki kebiasaan } \\
\text { berpikir positif. }\end{array}$ \\
\hline & \multirow[t]{3}{*}{ c. Pengetahuan } & $\begin{array}{l}\text { 1) Catat bidang-bidang ilmu, wawasan dan keterampilan yang ingin kamu pelajari, } \\
\text { baik secara langsung maupun melalui media digital. }\end{array}$ \\
\hline & & $\begin{array}{l}\text { 2) Buat jadwalnya dalam waktu satu minggu, seperti setiap Senin-Rabu pukul } \\
19.00-20.00 \text {. }\end{array}$ \\
\hline & & $\begin{array}{l}\text { 3) Catatlah kemajuannya setiap minggu. Jika ini dilakukan terus, pengetahuan } \\
\text { dan keterampilan mu akan terus bertambah seiring waktu. }\end{array}$ \\
\hline
\end{tabular}

3. Kepemimpinan

a. Berani Bertindak

1) Buatlah perencanaan usaha sederhana

2) Cobalah untuk mulai menjual produk atau membuat produk untuk dijual

3) Lakukan dan eksekusi langsung. Jika ada kesalahan, belajarlah dari kesalahan tersebut dan perbaiki agar lebih baik.

4) Hal yang paling penting dalam latihan ini adalah berani untuk langsung melakukan eksekusi rencana.

b. Tim yang Baik $\quad$ 1) Mulai saat ini, coba untuk ikut organisasi yang berhubungan dengan minat kamu atau mengikuti kegiatan kelompok.

2) Dengan kegiatan kelompok, kamu akan terbiasa untuk bekerjasama dengan banyak orang serta mengalami suka dukanya.

3) Hal ini akan menempamu untuk menjadi pribadi yang bisa bekerjasama dalam tim dan mengetahui karakter anggota tim yang bisa bekerjasama untuk menjadi tim juara.

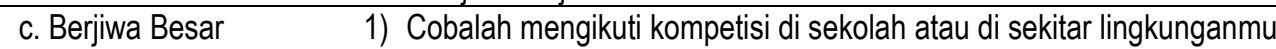

2) Berlatih untuk menerima dengan besar hati jika mengalami kekalahan

d. Mengambil Resiko 1) Latihannya sama dengan "berani bertindak" hanya saja kamu perlu menambahkan analisis resiko dari tindakanmu secara sederhana dan membuat langkah antisipasi jika ternyata risiko tersebut menjadi kenyataan.

2) Berani mengambil risiko bukan berarti nekat atau tanpa perhitungan. Biasakan menganalisis dan melakukan perhitungan cermat sebelum berani mengambil risiko.

e. Memiliki Mentor $\quad$ 1) Coba dekati dan banyak belajar dari mentor-mentor terbaik di bidangnya yang berada di sekitarmu.

2) Dengan banyak belajar dari mentor-mentor terbaik, ilmu dan kemampuanmu akan semakin meningkat. 


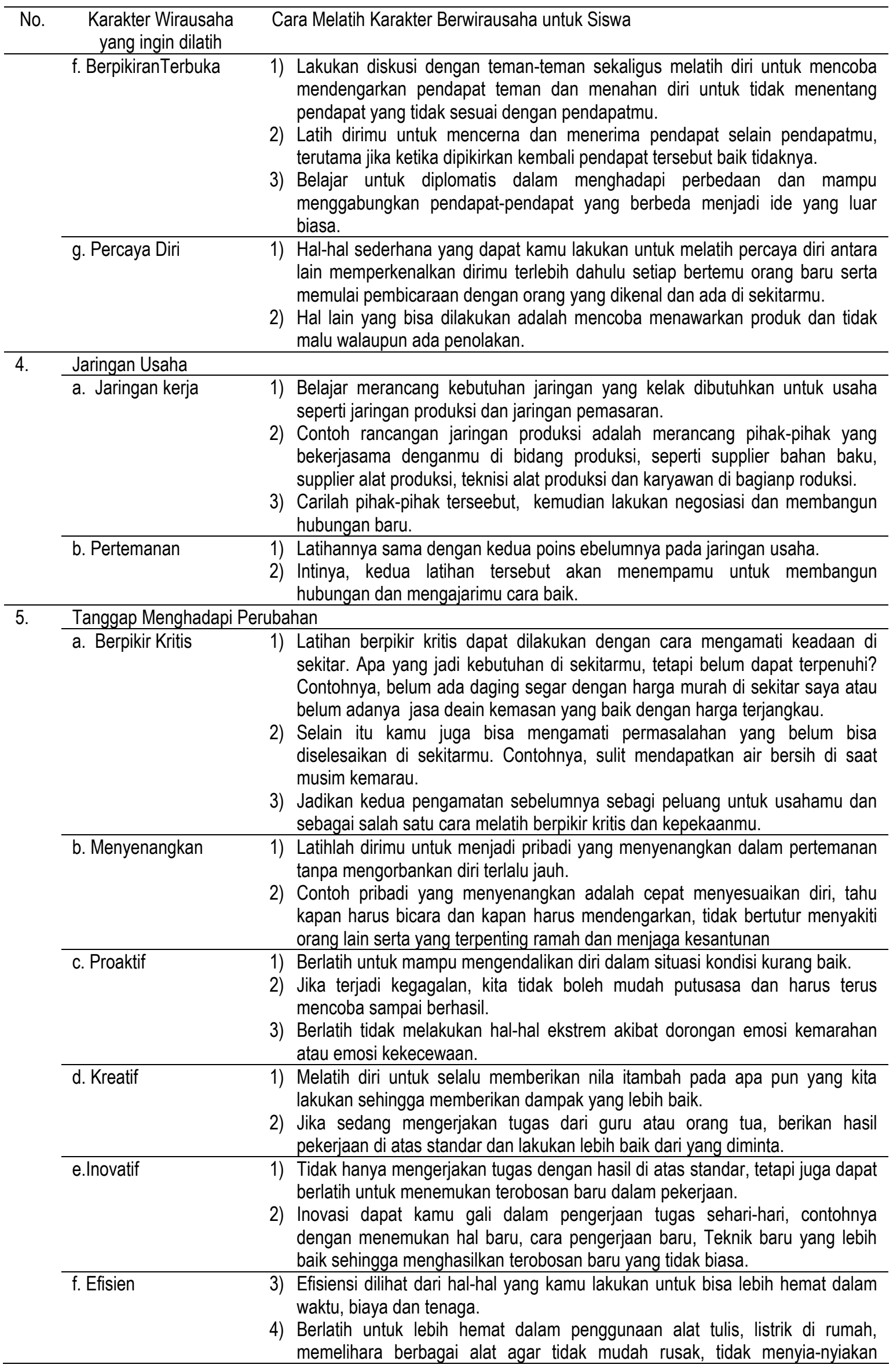




\begin{tabular}{ccc}
\hline No. & $\begin{array}{c}\text { Karakter Wirausaha } \\
\text { yang ingin dilatih }\end{array}$ & Cara Melatih Karakter Berwirausaha untuk Siswa \\
\hline & makan dan tidak membuang-buang waktu untuk hal yang kurang bermanfaat. \\
\hline
\end{tabular}

\section{Pemasaran Online}

Pemasaran digital (digital marketing) merupakan perpaduan yang saling terintegrasi dan terencana mengenai pemanfaatan sosial media, mesin pencari, surat elektronik dan juga konten yang tepat untuk mempromosikan usaha atau bisnis yang dimiliki. Kenyataannya, mengelola media tersebut tidak semudah kenyataannya. Banyak pengusaha kecil gagal mengelola media daring yang mereka miliki. Penyebab kegagalan tersebut antara lain karena kurangnya pengetahuan, tidak meluangkan waktu untuk mengelolanya dan tidak memiliki pengalaman yang cukup. Ketiga kekurangan tersebut cukup dominan dan menjadi penyebab kekalahan usaha kecil dalam bersaing dengan usaha lain yang telah mapan. Kesimpulannya ilmu pengetahuan sekaligus praktik merupakan hal penting yang sebaiknya dimiliki pengusaha. Hal ini untuk mendapatkan perhatian konsumen yang sebagian besar telah beralih ke dunia digital, khususnya ponsel pintar.

Pada era digital saat ini, segala aspek fisik perlahan diubah menjadi digital, menjadikan bisnis fisik harus mulai beralih ke dunia digital. Hal init erutama di bidang pemasaran dan hamper seluruh aspek kehidupan manusia terhubung dengan internet. Indonesia setidaknya ada 100 juta orang pengguna ponsel pintar. Artinya, hamper setengah warga negara Indonesia dapat dihubungi melalui ponsel pintar. Ini merupakan kesempatan yang cukup besar dan harus dimanfaatkan oleh setiap pengusaha. Peluang-peluang pemasaran online harus dimanfaatkan dan segera dikerjakan.

Untuk melatih karakter wirausaha pada siswa kelas XII OTKP 3 maka perlu adanya pembimbingan sebelum mereka praktek melakukan pemasaran online. Berikut ini disajikan beberapa contoh hasil pelatihan yang dilakukan siswa setelah mereka faham karakter kewirausahaan. Kegiatan praktek yang merekalakukan adalah:

\section{Menentukan jenis produk}

Dalam menentukan jenis produk ini siswa diarahkan untuk melakukan survey kecil-kecilan terhadap produk yang sedang diminati dan laris di pasaran. Selain itu juga produk yang akan dipasarkan harus disesuaikan dengan budget atau anggaran keuangan mereka serta kemampuan mereka.

\section{Membuat logo dan brosur produk}

Di sini guru mengajari siswa membuat sebuah logo dan brosur produk yang baik dan menarik dengan menggunakan beberapa macam aplikasi misalnya memakai aplikasi online canva atau aplikasi editing foto yang lain seperti Microsoft Publisher, Photoshop dan sebagainya. Dalam pembuatan logo dan brosur haruslah menarik dan tidak boleh sama dengan produk lain yang sudah beredar di masyarakat. Untuk itulah siswa dituntut untuk berkarya sekreatif mungkin. Dalam hal ini guru selalu siap menerima konsultasi siswa terhadap apa yang telah dibuatnya serta memberi saran terbaik bagi siswa agar menghasilkan karya yang baik dan menarik. Berikut ini disajikan salah satu contoh hasil karya siswa yang telah membuat logo dan brosur produk yang akan mereka jual secara online.

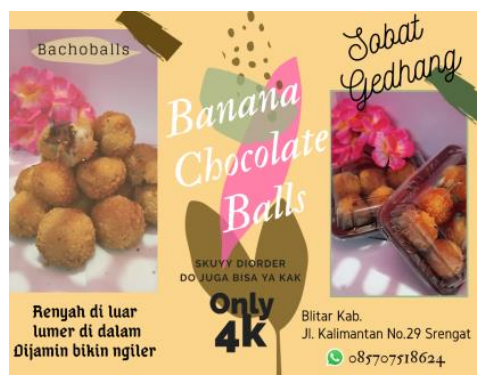

Gambar 1. Brosur produk karya siswa dalam penjualan online 


\section{Membuat proposal usaha}

Setelah siswa dapat membuat logo dan brosur, selanjutnya siswa dibimbing untuk membuat proposal usaha. Dalam proposal tersebut dicantumkan analisis SWOT dan juga perhitungan anggaran mulai pengadaan bahan baku sampai pengolahan produk jadi untuk dikemas dan dijual. Di sini siswa diarahkan agar berhati-hati dalam menentukan anggaran biaya dan penentuan harga jual produk. Siswa yang kurang teliti dalam memperhitungkan biaya dan harga jual maka akan mengakibatkan kerugian di kemudian hari.

\section{Membuat produk dan melakukan promosi pemasaran online}

Setelah siswa selesai membuat produk, saatnya praktek memasarkan produknya lewat media social seperti melalui Whatsapp, Instagram, market place Facebook dan Youtube. Namun untuk praktek kali ini siswa cenderung banyak menggunakan Whatsapp dan Youtube. Berikut ini contoh karya siswa yang sudah diupload di Youtube.

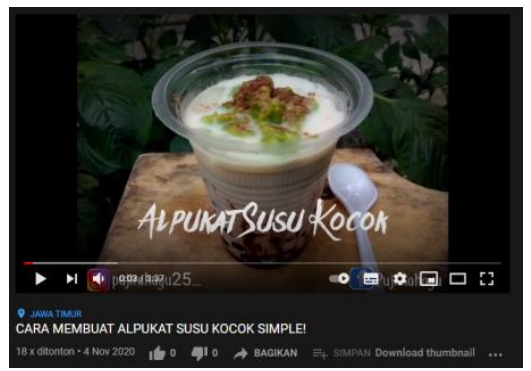

Gambar 2. Hasil karya siswa yang dipasarkan melalui Youtube (https://youtu.be/3NEs7qsgCOg

\section{Membuat Laporan Usaha}

Langkah terakhir setelah melakukan pemasaran online maka siswa diminta untuk membuat laporan usaha. Berikut ini disajikan tabel daftar nama siswa yang melakukan pemasaran online beserta omzet, laba yang mereka peroleh dari bisnisnya. Berikut ini disajikan data hasil kegiatan pemasaran online yang dilakukan oleh siswa.

Tabel 2. Hasil pemasaran produk secara online oleh siswa

\begin{tabular}{rllr} 
NO. & & \multicolumn{1}{c}{ NAMA LENGKAP } & \multicolumn{1}{c}{$\begin{array}{c}\text { NAMA PRODUK } \\
\text { (Rp) }\end{array}$} \\
\hline 1 & OVELIA DIRGAHAYU N. & Bola-bola Isi & - \\
\hline 2 & PRYTIA SINTA YUNITA DEWI & KeripikSingkongKriuk & 9.000 \\
\hline 3 & PUJI RAHAYU & AlpukatSusuKocok & 31.000 \\
\hline 4 & PUTRI FIDIANTI & KeripikSingkongMakTi & 60.000 \\
\hline 5 & PUTRI REDINA PRAYOGO & Makeup dan Fashion & - \\
\hline 6 & RAHMA RIZKY ANI & Banana Chocolate & 15.000 \\
\hline 7 & RAKHEL NOVITASARI & Masker organikcoklat & 72.000 \\
\hline 8 & RATNA DWI LESTARI & WeciSayur & 4.500 \\
\hline 9 & REVIKA SEKAR NANDITA & Pisang Coklat Smooth & 36.000 \\
\hline 10 & RIA AYU FERNANDA & Milk Shake & - \\
\hline 11 & RIDA RAHMAWATI & Mie Gacoan & - \\
\hline 12 & RIKA AYU WULANDARI & Banana Chocolate Ball & 24.000 \\
\hline 13 & RISKA PRIANTIKA & Bola-bola pisang coklat & 7.100 \\
\hline 14 & RIZKY AYU PAMBUDI & Pisang coklat & - \\
\hline 15 & SAGITA DESI AL-FITRIANI & Chocolate melt & 179.500 \\
\hline 16 & SALSABILA DWI ERINDA & Sweet desert box chocolatos & 9.000 \\
\hline 17 & SALSABILLA NUR IZZATI & Masker wajahorganik & 30.000 \\
\hline 18 & SHENLY ANGGITA IRDHIA S. & Kalungkekinian & 15.000 \\
\hline 19 & SILVANA KISSY AMANDA & Seblakkeringsetan & 55.500 \\
\hline 20 & SILVI LUTVIANA & Salad buah & 20.000 \\
\hline 21 & SILVI TANIA & Telurgeprek huh hah & 32.000 \\
\hline & & & \\
\hline
\end{tabular}




\begin{tabular}{rllr}
\hline NO. & \multicolumn{1}{c}{ NAMA LENGKAP } & \multicolumn{1}{c}{ NAMA PRODUK } & $\begin{array}{r}\text { LABA } \\
\text { (Rp) }\end{array}$ \\
\hline 22 & SRI BELLA PUTRI RAHAYU & Mie Sedap Huh Hah & 10.000 \\
\hline 23 & SUCIANINGRUM & TahuMercon & 88.000 \\
\hline 24 & SUKMA AYU TRIHAPSARI & Masker Organik mint & 30.000 \\
\hline 25 & SUSANA YULIANTI & Multi beauty soap & 73.000 \\
\hline 26 & TITIS HERLIANA DEWI & Keripik talas & - \\
\hline 27 & VIOLIN YURA ANGELINA & Dessert Box Red Velvet & 5.000 \\
\hline 28 & VIVIAN REVAENELLA A. & PentolMercon & 28.000 \\
\hline 29 & WINDY ARISKA APRITASARI & Bola-bola Ubi & 5.000 \\
\hline 30 & WIWIT SULISTYOWATI & Cimolmontoks & - \\
\hline 31 & YOLA DWI NUR RAHAYU & SusuKurma & - \\
\hline 32 & YULI SETYORINI & TahuNdower & 60.000 \\
\hline 33 & YULIA YESINTA & Jamur Crispy & \\
\hline
\end{tabular}

Melatih karakter kewirausahaan siswa harus diawali dengan motivasi terlebih dahulu kepada siswa agar memiliki semangat untuk melakukan kegiatan praktek selanjutnya. Hal ini sejalan dengan (Rufaidah and Kodri, 2020), yang menyatakan bahwa inovasi dan kreativitas merupakan hal yang paling menentkan dalam membentuk jiwa kewirausahaan di era Revolusi 4.0. Guna mencapai sikap kewirausahaan tersebut kegiatan ini diawali dengan karakter motivasi berprestasi, sudah menunjukkan hasil yang signifikan dimana anak-anak mau bekerja keras mengawali proses berjualan online dengan penuh semangat. Setidaknya siswa sudah memiliki gambaran orientasi kedepan jika sewaktu-waktu harus melakukan pemasaran online sudah memiliki bekal pengetahuan tentang cara membuat logo, brosur, proposal dan teknik memasarkan melalui media sosial. Dalam hal kepemimpinan siswa sudah menunjukkan kerjasama dengan orang lain untuk merealisasikan pemasaran produk secara online. Untuk jaringan usaha belum begitu tampak sebab praktek memasarkan produk masih dilakukan sekali. Akan tetapi mereka tetap diarahkan untuk bisa bekerjasama dengan orang-orang sekitar misalnya dengan membuka kesempatan menjadi reseller. Siswa juga dibekali karakter untuk tanggap meghadapi perubahan sehingga akan terpacu untuk mengembangkan diri dengan inovasi dan kreatifitas.

Dari hasil praktek siswa sebagaimana di paparkan di atas dapat dipaparkan bahwa dari 33 siswa, mayoritas memasarkan produknya berupa kuliner yaitu 28 orang, sementara 4 orang memasarkan produk kosmetik dan 1 orang memasarkan produkak asesoris. Dari seluruh siswa yang telah memasarkan produknya tersebut memang tidak semuanya mendapatkan laba. Hal ini dapat dilihat ada 9 siswa yang tidak mendapatkan laba, sedang 24 siswa yang lain mendapatkan laba yang bervariasi. Menurut informasi siswa yang tidak memperoleh laba karena beberapa faktor. Salah satu faktornya mereka kurang telaten melakukan pemasaran produk sehingga setelah membuat hanya sekedar dipromosikan dan terjual tidak sesuai target. Faktor lain terdapat kesalahan dalam memperhitungkan harga jual sehingga antara modal dengan hasil yang didapatkantidakseimbang. Dan faktor yang kebanyakan dialami yaitu produk tidak laku terjual karena kurang adanya minat dari konsumen untuk membeli produk tersebut.

Dari 33 siswa yang telah melaksanakan kegiatan pemasaran online tersebut setelah dievaluasi kurang lebih 3 bulan kemudian, ternyata masih ada yang tetap menjalankan bisnisnya terutama di bidang kosmetik, kuliner dan fashion. Sedangkan siswa lainnya lebih memilih berhenti berbisnis karena ingin fokus belajar menghadapi ujian sekolah dan uji kompetensi siswa. 


\section{SIMPULAN}

Berdasarkan paparan di atas dapat disimpulkan bahwa sebelum melatih jiwa kewirausahaan terhadap siswa maka guru perlu memahami terlebih dahulu karakter seperti apa yang perlu ditumbuhkan pada diri siswa. Beberapa karakter kewirausahaan yang dapat dilatihkan ke siswa diantaranya motivasi berprestasi, orientasi kedepan, kepemimpinan, jaringan usaha dan tanggap menghadapi perubahan. Selanjutnya setelah menanamkan jiwa tersebut dalam diri siswa maka siswa dibimbing untuk melakukan praktik nyata dengan melakukan tahapan-tahapan pemasaran online. Mulai dari cara membuat proposal usaha sampai dengan memasarkan produk melalui media sosial baik Whats App, Marketplace Facebook, Instagram maupunYoutube.

Setelah semua aktifitas pembelajaran baik teori maupun praktik tersebut dilakukan maka saatnya guru dan siswa saling melakukan refleksi terhadap kegiatan yang telah dilakukan. Siswa harus bisa lebih terbuka mental dan hatinya untuk mau dilatih karakter kewirausahaan sehingga mereka akan lebih rela atau ikhlas melaksanakan intruksi guru. Sementara guru harus lebih bijak dan semangat mendampingi para siswa selama proses pemasaran online sehingga bisa memberikan konsultasi yang penuh kepada siswa yang mengalami kesulitan. Program melatih karakter kewirausahaan pada siswa ini harus terus dilaksakan secara terus menerus. Demikian pula untuk guru harus terus memotivasi siswanya untuk terusmelanjutkan kegiatan pemasaran online nya terutama jikas udah lulus nanti sehingga siswa tidak bingung mencari-cari pekerjaan, melainkan mereka sudah menciptakan lapangan kerja sendiri. Guru perlu sesekali memantau tindak lanjut dari pemasaran online yang dilakukan siswa ketika sudah lulus sekolah dengan menanyakan bagaimana perkembangan bisnis mereka sehingga guru punya data base terhadap siswa yang mau berwirausaha.

\section{SARAN PENGEMBANGAN PENELITIAN LANJUT (FUTURE RISET)}

Penelirian ini merupakan penelitian tidakan kelas atas mata pelajaran kewirausahaan dengan menggunakan metode pemasaran online. Tentu penelitian yang sederhana ini masih banyak kelemahan, baik dalam metode, pengukuran kompetensi siswa dalam berwirausaha maupun kedalaman analisisnya. Penelitian terkait kewirausaan dengan subyek penelitian siswa perlu dikembangan secara berkelanjutan ke depannya, misalnya terkait efektivitas metode pembelajaran praktik tertentu dalam kewirausahaan, factor-faktor yang berperan atau yang mempengaruhi keberhasilan siswa dalam menjalankan wirausaha dan banyak topic lain yang bisa dikembangkan, namun, bagaimanapun penelitian ini dapat memberikan sumbangsih dalam memperkaya referensi atau rujukan bagi penelitian selanjutnya.

\section{DAFTAR RUJUKAN}

Ahmad, A. (2021) 'Ekonomi Kreatif Sub-Sektor Kuliner Dalam Menunjang Pertumbuhan Ekonomi Masa Pandemi Di Blitar', JUPEKO: Jurnal Pendidikan Ekonomi, 6(1), pp. 35-38. doi: https://doi.org/10.29100/jupeko.v6i1.1916.

Anas, M. (2019) 'Penerapan Model Pembelajaran Kooperatif Berbasis Kasus Berpusat Kepada Mahasiswa Pada Mata Kuliah Auditing 1', Prosiding Seminar Nasional Manajemen, Ekonomi, Akuntansi, pp. 427-435. Available at:

http://ojs.senmea.fe.unpkediri.ac.id/index.php/senmea/article/view/54.

Anas, M., Riani, L. P. and Lianawati, D. (2019) 'Potret Ketimpangan Distribusi Pendapatan Di Indonesia Tahun 2018 Dengan Indikator Rasio Gini, Kurva Lorentz, dan Ukuran Bank Dunia', Seminar Nasional Manajemen Ekonomi dan Akuntansi (SENMEA) IV Tahun 2019 Fakultas Ekonomi UN PGRI Kediri, pp. 72-83. Available at:

http://ojs.senmea.fe.unpkediri.ac.id/index.php/senmea/article/view/19/29.

Artantri, M. W. et al. (2021) 'The Development of Digital-Based Economics in Sustaining Interest in 
Shopping Online through the Marketplaces during the COVID-19 Pandemic', 8(March), pp. 260-268. Available at: https://www.ijrjournal.com/IJRR_Vol.8_Issue.3_March2021/IJRR034.pdf.

Atiya, T. and Osman, Z. (2021) 'The effect of entrepreneurial characteristics on the entrepreneurial intention of university students in Oman and Sudan', Entrepreneurship and Sustainability Issues, 8(4), pp. 217-234. doi: 10.9770/jesi.2021.8.4(12).

Brown, C. and Thornton, M. (2011) 'Entrepreneurship Theory and the Creation of Economics : Insights From Cantillon 'S Essai', Nature, pp. 101-113.

Cherukara, J. and Manalel, J. (2011) Evolution of Entrepreneurship theories through different schools of thought.

Fierro, F. and Andrade, J. M. (2021) 'The complex relationship between entrepreneurship and its context', Entrepreneurship and Sustainability Issues, 8(4), pp. 235-249. doi: 10.9770/jesi.2021.8.4(13).

Gawel, A. (2021) 'The gender-based attainment of education and female entrepreneurship: the European perspective', Entrepreneurship and Sustainability Issues, 8(4), pp. 403-417. doi: 10.9770/jesi.2021.8.4(24).

Grebel, T. (2004) Entrepreneurship: A new perspective, Entrepreneurship: A New Perspective. doi: $10.4324 / 9780203478745$.

Handayani, S. et al. (2021) 'Peningkatan Young Enterpreneur Di Masa Pandemi Covid-19 Melalui Pengeolaan Ekonomi Kreatif', Jurkami, 6(1), p. 2021. doi: https://doi.org/10.31932/jpe.v6i1.

Jayanti, S. N. et al. (2021) 'Micro , Small and medium Enterprises ' Defense among Pandemic Covid-19', International Journal of Advances in Enginering and Management (IJAEM), 3(5), pp. 1318-1326. doi: 10.35629/5252-030513181326.

McFarlane, J. (2016) 'Economic Theories of Entrepreneurship', Enterprise: Concepts and Issues. doi: 10.23912/978-1-910158-75-3-2880.

Megawati and Farida, L. (2018) 'Strategi menumbuhkan jiwa kewirausahaan yang kreatif dan inovatif', Prosiding Seminar Nasional ASBIS, 2(2), pp. 296-302.

Rufaidah, E. and Kodri (2020) 'Buku Referensi: Strategi Inovasi dan Kreativitas Berwirausaha Era Revolusi 4.0 (Kajian Empiris \& Kajian Literatur)', 0.

Zhuravlov, D. et al. (2021) 'The impact of the public debt of a country on the sustainable development of entrepreneurship', Entrepreneurship and Sustainability Issues, 8(4), pp. 654-667. doi: 10.9770/jesi.2021.8.4(40). 